\title{
THE EVALUATION OF ORGANICALLY GROWN APPLE CULTIVARS FOR SPECIAL DIET PUREE PRODUCTION
}

\author{
Solvita Kampuse, Zanda Kruma, Dace Klava*, Liene Ozola, Ruta Galoburda, Evita Straumite \\ Department of Food Technology, Faculty of Food Technology, Latvia University of Life Sciences and Technologies, \\ Rigas iela 22, Jelgava, Latvia, e-mail: dace.klava@llu.lv
}

\begin{abstract}
The aim of this research was to evaluate organically grown Latvian extensive apple cultivars for production of puree for special diets with high content of bioactive compounds. Five organically grown extensive cultivars were selected for evaluation within the project: 'Antonovka', 'Filippa', 'Nicnera Zemenu', 'Rudens Svitrotais', 'Sipolins'. All these apple cultivars were evaluated fresh and after processing into puree. The content of soluble solids, titratable acids, vitamin $\mathrm{C}$, total carotenes, total phenols, total flavonoids, antiradical activity (DPPH and $\mathrm{ABTS}^{+}$), and $\mathrm{pH}$ were determined. The cultivars with the highest soluble solids content both fresh and puree were 'Nicnera Zemenu' and 'Sipolins' with 12.7 to 13.5 Brix\%, but the lowest $\mathrm{pH}$ value and the highest titratable acids content was detected in apple cultivar 'Antonovka'. Fresh apples of this cultivar showed also the highest vitamin C content (14.5 mg $\left.100 \mathrm{~g}^{-1}\right)$,

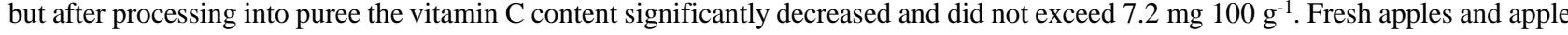
puree from cultivar 'Antonovka' had the highest content of total phenolics, total flavonoids and DPPH radical scavenging activity, whereas the lowest results showed fresh apples and puree of cultivar 'Sipolins'. Apples are not a source of caroteinoids therefore the

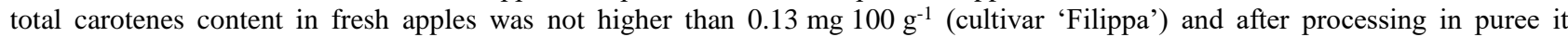
significantly $(\mathrm{p}<0.05)$ decreased. Apple processing had a significant $(\mathrm{p}<0.05)$ influence on the bioactive compounds in product.
\end{abstract}

Keywords: total carotenes, vitamin C, total phenols, antiradical activity

\section{Introduction}

Apples (Malus domestica L.) are one of the most consumed fruits in European Union (FernándezJalao et al., 2018) and are key ingredient of many traditional desserts due to their availability and versatility (Keenan et al., 2012). They are rich in phenol compounds, pectin, sugar, insoluble and soluble dietary fibre, macro- and microelements, which possess various health benefits (Kalinowska et al., 2014; Boyer, Liu, 2004). Many of health benefits associated with apples are due to their chemical composition, especially, rich polyphenol content. It has been well documented that the main polyphenols in apple fruits are flavan-3-ols (catechin, epicatechnin, proanthocyanidins) hydrocinnamic acis (chlorogenic acid, p-coumaroylquinic aid) dihydrochalcones and flavonols (quercetin, kaempferol), two glycosides of phloretin and anthocyanins (Archivio et al., 2007; Song et al., 2007; Weichselbaum et al., 2010). Health benefits associated with apple polyphenols are a risk reduction of cardiovascular disease, some types of cancer, diabetes, Alzheimer's disease (Laaksonen et al., 2017; Fernández-Jalao et al., 2018) and have a positive influence on blood lipid parameters and blood pressure in human beings (Weichselbaum et al., 2010). The presence of ascorbic acid in apples also contributes to the total antioxidant capacity of polyphenols (Karaman et al., 2013). However according to Drogoudi et al. (2008) vitamin C accounts only for $0.4 \%$ of antioxidant potential in apples.

When assessing the benefits of apples, it should be taken into account that the composition of natural phytochemicals varies notably depending on the variety, region and corresponding weather conditions, ripeness, agricultural practice, and post-harvest conditions (Keenan et al., 2012; Kalinowska et al., 2014; Jakobek,
Barron, 2016; Fernández-Jalao et al., 2018). Polyphenols in apple fruit play important role in the flavour and colour of apples and their processing products. When selecting apples for processing there are many other important fruit quality attributes such as soluble solids content, total titratable acidity, $\mathrm{pH}$, firmness (Bonany et al., 2014). The type of processing also will affect the quality of final product; therefore, it is important to evaluate the performance of the specific apple varieties in processed products. Apple purees are concentrated plant food dispersions where soft insoluble particles composed of cell particles from parenchyma are dispersed in an aqueous solution of sugars, organic acids and pectic substances (Espinosa et al., 2011). The composition of puree and its rheological properties greatly depend on the apple variety used.

Worldwide, dysphagia affects approximately 590 million people (Cichero et al., 2017), who need modified texture diets such as pureed foods to allow safe swallowing. Preparation of pureed foods requires disintegration of regular texture into smaller pieces which may result in a reduced nutritional value and appeal (Keller et al., 2012). This has practical implications for older adults with generally lower food intake (Pfisterer et al., 2018) and therefore malnutrition prevalence reached $80 \%$ among patients with dysphagia (Ercilla et al., 2012). Keller and Duizer (2014) discovered that limited variety can lead to sensory fatigue, and therefore variety should be increased through different ingredients, spices, sauces. Additionally, the thickness of puree has safety implications (Ilhamto et al., 2014).

The aim of this research was to evaluate organically grown Latvian extensive apple cultivars for production of puree for special diets with high content of bioactive compounds. 


\section{Materials and Methods}

Fresh apples

Five organically grown extensive cultivars from the farm Kurpnieki located in Aizpute region Laza parish were chosen for evaluation within the study 'Antonovka', 'Filippa', 'Nicnera Zemenu', 'Rudens Svitrotais', 'Sipolins'. All these apple cultivars were evaluated fresh, fully ripened within 1 to 2 weeks after harvesting and storage in refrigerator at $4-6{ }^{\circ} \mathrm{C}$, and after processing into puree.

\section{Apple puree preparation}

Apple puree from all 5 cultivars was produced by washing, cutting into $2 \times 2 \mathrm{~cm}$ pieces, heating in the steam cooker Philips HD 9126 for 25 min, blending with blender PHILIPS (30-40 s) into puree, and treating through sieves. The obtained apple puree was filled into $250 \mathrm{~mL}$ glass jars, covered and pasteurized at $90 \pm 2{ }^{\circ} \mathrm{C}$ for $5 \mathrm{~min}$.

Sample preparation for chemical and physical analyses An average sample from five fresh apples was homogenized for fresh analysis in addition to apple puree from the same cultivars.

\section{Determination of total carotenes content}

The total carotenes content was detected by spectrophotometric method with UV/VIS spectrophotometer Jenway 6705 (Bibby Scientific Ltd., UK) and method described by Kampuse et al. (2015) with modifications. Apple and apple puree sample of $4 \mathrm{~g}$ was mixed with $20 \mathrm{~mL}$ of ethanol on a magnetic stirrer for $15 \mathrm{~min} .25 \mathrm{~mL}$ of petroleum ether were added and stirred for an hour. After mixing, samples were left for half an hour for dividing of layers. The absorption at $440 \mathrm{~nm}$ of petroleum ether layer was measured. Analyses were done in two repetitions and the results were expressed as $\mathrm{mg} 100 \mathrm{~g}^{-1}$ fresh weight.

\section{Detection of ascorbic acid content}

This method determines L-ascorbic acid, which is the reduced form of ascorbic acid. The titration with $0.5 \mathrm{n}$ iodine solution was used according to method T-138-15-01:2002 (Seglina, 2007). Analyses were done in two replications and two repeated measurements. The results were expressed as $\mathrm{mg} 100 \mathrm{~g}^{-1}$ fresh weight.

\section{Determination of $p H$}

$\mathrm{pH}$ was measured $(\mathrm{n}=3)$ by $\mathrm{pH}$-meter (JENWAY 3510, Baroworld Scientific Ltd., UK) using standard method LVS ISO1842:1991.

Determination of apple and apple puree soluble solids content

The soluble solids content (Brix\%) was measured with digital refractometer Refracto 30GS (Mettler Toledo, Japan) using standard method ISO 2173:2003. Measurements were carried out in five replications.

\section{Determination of titratable acidity}

Total titratable acids were determined by titration with $0.1 \mathrm{~N} \mathrm{NaOH}$ (ISO 750:1998) in fresh apples and apple puree. The results were expressed in $\mathrm{g} 100 \mathrm{~g}^{-1}$ fresh weight.

\section{Extraction of phenolic compounds}

For extraction of phenolic compounds five fresh apples were homogenised (combined sample containing pulp and peel). $5 \mathrm{~g}$ of homogenised fresh apples and apple purees were extracted with $50 \mathrm{~mL}$ ethanol/water solutions (80\%) in an ultrasonic bath YJ5120-1 (Oubo Dental, USA) at $35 \mathrm{kHz}$. Extraction parameters: temperature $20^{\circ} \mathrm{C}$; solid to liquid ratio $1: 10$, time 20 minutes.

\section{Determination of total phenolic compounds}

The total phenolic content (TPC) of the fresh apples and apple purees was determined according to the Folin-Ciocalteu spectrophotometric method (Singleton et al., 1999). The absorbance was measured at $765 \mathrm{~nm}$ and total phenols were expressed as the gallic acid equivalents (GAE) $100 \mathrm{~g}^{-1}$ fresh weight.

\section{Determination of total flavonoid compounds}

The total flavonoid content (TFC) was measured by a spectrophotometric method (Kim et al., 2003). The absorbance was measured at $415 \mathrm{~nm}$ and total flavonoids were expressed as catechin equivalents (CE) $100 \mathrm{~g}^{-1}$ fresh weight.

\section{Determination of antioxidant activity}

Antioxidant activity of the extracts was measured on the basis of scavenging activities of the stable 2,2-diphenyl1-picrylhydrazyl (DPPH') radical as outlined by Yu et al. (2003). The absorbance was measured at $517 \mathrm{~nm}$. Activity also was measured by 2,2-azino-bis(3ethylbenz-thiazoline-6-sulfonic) acid (ABTS ${ }^{+}$) radical cation assay (Floegel et al., 2011). The absorbance was measured at $734 \mathrm{~nm}$. Antioxidant activity was expressed as mmol TE $100 \mathrm{~g}^{-1}$ fresh weight.

\section{Statistical analysis}

Experimental results are means of three replications (if not stated different) and were analysed by Microsoft Excel 2010 and SPSS 17.00. Analysis of variance (ANOVA) and Tukey's test were used to determine differences among samples. Differences were considered as significant at $\mathrm{p}<0.05$. A linear correlation analysis was performed in order to determine relationship between TPC, TFC, antioxidant activity such as $\mathrm{DPPH}^{\cdot}$ and $\mathrm{ABTS}^{\cdot+}$ antioxidant activity.

\section{Results and Discussion}

\section{Ascorbic acid content}

The ascorbic acid content of five organically grown old apple cultivar fresh apples was between 7.71 to $14.51 \mathrm{mg} 100 \mathrm{~g}^{-1} \mathrm{FW}$ (Table 1). As it is mentioned also in literature apples are not an important source of ascorbic acid. In evaluation of 71 Danish apple cultivars, authors Varming et al. (2013) found that ascorbic acid content ranged from less than 1 to $27 \mathrm{mg} 100 \mathrm{~mL}^{-1}$.

After production of puree the ascorbic acid content significantly $(p=0.000)$ decreased by $11.5-59.3 \%$ in almost all cultivars. The biggest losses of ascorbic acid 
content were detected for cultivars with the highest content of this vitamin in fresh stage (Table 1). Therefore, the differences of ascorbic acid content in fresh apples were significant $(\mathrm{p}=0.000)$ but after processing puree the ascorbic acid content in puree of all cultivars was similar $(\mathrm{p}=0.22)$. As it is mentioned in investigations with strawberries of Hartmann et al. (2008) the content of ascorbic acid, in comparison to that in the frozen strawberries, decreased significantly during the processing of the fruit to puree by $77 \%$. As these authors noticed the pasteurization of purees at $85^{\circ} \mathrm{C}$ for 2 min was the processing step causing the highest losses for the most parameters (Hartmann et al., 2008).

Table 1

Ascorbic acid and total carotenes content in fresh apples and purees

\begin{tabular}{lcc}
\hline Cultivar & $\begin{array}{c}\text { Ascorbic acid } \\
\text { content, } \\
\text { mg 100 g-1 }\end{array}$ & $\begin{array}{c}\text { Total carotenes } \\
\text { content, } \\
\text { mg 100 g-1 }\end{array}$ \\
\hline $\begin{array}{l}\text { Fresh apples } \\
\text { 'Antonovka' }\end{array}$ & $14.51 \pm 0.35^{\mathrm{d}}$ & $0.077 \pm 0.001^{\mathrm{b}}$ \\
'Filippa' & $12.70 \pm 0.68^{\mathrm{c}}$ & $0.132 \pm 0.001^{\mathrm{d}}$ \\
'Nicnera Zemenu' & $8.84 \pm 0.58^{\mathrm{b}}$ & $0.056 \pm 0.006^{\mathrm{a}}$ \\
'Rudens Svitrotais' & $7.71 \pm 0.48^{\mathrm{a}}$ & $0.104 \pm 0.002^{\mathrm{d}}$ \\
'Sipolins' & $8.99 \pm 0.38^{\mathrm{b}}$ & $0.094 \pm 0.002^{\mathrm{c}}$ \\
\hline Apple puree & & \\
'Antonovka' & $6.17 \pm 0.47$ & $0.066 \pm 0.003^{\mathrm{b}}$ \\
'Filippa' & $5.16 \pm 0.40$ & $0.068 \pm 0.005^{\mathrm{b}}$ \\
'Nicnera Zemenu' & $7.21 \pm 0.40$ & $0.042 \pm 0.001^{\mathrm{a}}$ \\
'Rudens Svitrotais' & $6.82 \pm 0.77$ & $0.065 \pm 0.003^{\mathrm{b}}$ \\
'Sipolins' & $6.00 \pm 1.21$ & $0.076 \pm 0.002^{\mathrm{c}}$ \\
\hline
\end{tabular}

Different letters in the same column represents significant differences between values (Tukey's test, $\mathrm{p}<0.05$ ) for fresh apples and apple purees separately.

\section{Total carotenes}

The total carotenes content in all apple cultivars was low, 0.056-0.132 mg $100 \mathrm{~g}^{-1} \mathrm{FW}$ (Table 1) and after processing similarly to ascorbic acid significantly decreased $(p=0.000)$. The content of total carotenoids in other studies was from 26.16 \pm 0.99 to $37.02 \pm 0.69 \mu \mathrm{g} \mathrm{g}^{-1} \quad \mathrm{DW}$ (or calculating to fresh weight about $0.52-0.74 \mathrm{mg} 100 \mathrm{~g} \mathrm{~g}^{-1}$ ) (DelgadoPelayo et al., 2014).

The cultivar had significant effect on the amount of total carotenes content both in fresh and processed apples $(p=0.000)$. The highest content of total carotenes was detected in 'Filippa' fresh apples and 'Sipolins' apple puree (Table 1).

\section{Changes of $\mathrm{pH}$}

$\mathrm{pH}$ is an important factor influencing both product acidity and safety of product. If the product is considered for special diets of people after operations or old people it is not recommended to consume products with low $\mathrm{pH}$ value. $\mathrm{pH}$ value of fresh apples of different evaluated cultivars was in the range of 2.97-3.33 (Table 2). After processing of puree slight increase of $\mathrm{pH}$ in cultivars 'Nicnera Zemenu' and 'Sipolins' was detected. The cultivar 'Nicnera Zemenu' had the highest $\mathrm{pH}$ value both in fresh apples and puree. The $\mathrm{pH}$ of cultivar
'Antonovka' was even lower than 3.0 and therefore this cultivar is not recommended for puree of special diets.

\section{Titratable acids content}

The titratable acids content characterising the total amount of organic acids in the product gives also the sensory acid taste feeling. This parameter has also negative correlation with $\mathrm{pH}$ value therefore the best sample for special diet purpose is the cultivar with the lowest titratable acids content which again was cultivar 'Nicnera Zemenu' both for fresh apples and also puree (Table 2). There were significant differences $(p=0.000)$ between cultivars in titratable acids content what proves the importance of cultivar for choosing raw material for processing puree for special diet purposes.

Table 2

Titratable acid, $\mathrm{pH}$ value and soluble solid content in fresh apples and purees

\begin{tabular}{lccc}
\hline Cultivar & $\begin{array}{c}\text { Titratable } \\
\text { acids, } \\
\text { g 100 g-1 }\end{array}$ & $\begin{array}{c}\text { Soluble } \\
\text { solids } \\
\text { content, } \\
\text { Brix \% }\end{array}$ & $\begin{array}{c}\text { pH } \\
\text { value }\end{array}$ \\
\hline $\begin{array}{l}\text { Fresh apples } \\
\text { 'Antonovka' }\end{array}$ & $1.11 \pm 0.003^{\mathrm{c}}$ & $10.65 \pm 0.06^{\mathrm{a}}$ & 2.97 \\
'Filippa' & $0.70 \pm 0.006^{\mathrm{b}}$ & $10.63 \pm 0.05^{\mathrm{a}}$ & 3.10 \\
'Nicnera Zemenu' & $0.61 \pm 0.007^{\mathrm{a}}$ & $13.50 \pm 0.22^{\mathrm{c}}$ & 3.33 \\
'Rudens Svitrotais' & $0.68 \pm 0.001^{\mathrm{ab}}$ & $12.25 \pm 0.24^{\mathrm{b}}$ & 3.26 \\
'Sipolins' & $0.71 \pm 0.004^{\mathrm{b}}$ & $12.78 \pm 0.31^{\mathrm{b}}$ & 3.22 \\
\hline Apple puree & & & \\
'Antonovka' & $1.028 \pm 0.001^{\mathrm{d}}$ & $10.87 \pm 0.05$ & 2.97 \\
'Filippa' & $0.67 \pm 0.000^{\mathrm{c}}$ & $10.90 \pm 0.08$ & 3.15 \\
'Nicnera Zemenu' & $0.55 \pm 0.009^{\mathrm{a}}$ & $13.48 \pm 0.36$ & 3.38 \\
'Rudens Svitrotais' & $0.64 \pm 0.007^{\mathrm{b}}$ & $11.80 \pm 0.45$ & 3.26 \\
'Sipolins' & $0.74 \pm 0.005^{\mathrm{d}}$ & $13.40 \pm 0.29$ & 3.31 \\
\hline
\end{tabular}

Different letters in the same column represents significant differences between values (Tukey's test, $\mathrm{p}<0.05$ ) for fresh apples and apple purees separately.

\section{Soluble solids content}

The soluble solids content is another factor, which influences the overall sensory profile of each product responsible mostly for sweet taste of product. The minimal allowed soluble solids content in apple juices and purees according to norms is $11.2 \%$ (according to the regulation of the Cabinet of Ministers of Latvia no. 1113, October 15, 2013). Cultivars 'Antonovka' and 'Filippa' had lower soluble solids content and therefore they are less suitable for processing puree. The cultivar 'Nicnera Zemenu' both for fresh apples and also puree had the highest soluble solids content. This cultivar significantly $(\mathrm{p}=0.000)$ differed from all other cultivars except puree of 'Sipolins' (Table 2).

\section{Phenolic compounds and antioxidant activity}

Comparing total phenols content of different cultivar apples, the highest content was detected in the $\mathrm{cv}$. 'Antonovka', followed by 'Filippa' and 'Nicnera Zemenu' (Table 3). Francini and Sebastiani (2013) summarised different studies about phenolic compounds in apples and concluded that it ranges from 68.29 to $73.96 \mathrm{mg}$ GAE $100 \mathrm{~g}^{-1} \mathrm{FW}$, on average, depending on the pulp colour. Latvian apples showed higher TPC 
except cultivar 'Sipolins', and significantly higher content was found in cv. 'Antonovka' $115 \mathrm{mg}$ GAE $100 \mathrm{~g}^{-1} \mathrm{FW}$.

Also, high phenolic content in 'Antonovka' apples grown in Georgia was detected (Gogia et al., 2014). In apple puree content of phenolics was 1.7 up to 2.4 times higher than in apples, possibly due to change in sample concentration during puree preparation. In apple purees the highest content was in samples made from 'Antonovka' and 'Nicnera Zemenu'. There are no data about purees of analysed cultivars, but comparing ciders from dessert apples, the highest TPC was detected for the cultivar 'Antonovka' sample, showing similar tendency as our results (Riekstina-Dolge et al., 2014).
There are no general guidelines for consumption of phenolics, because it depends on the structure of each compound and as the health claim with scientifically proved efficiency, only for olive polyphenols is confirmed. In literature, it is possible to find different studies about general consumption of phenolics in diet. For comparison, data from Poland was selected because there are more similar eating habits to Latvia, and daily dietary intake was $989 \mathrm{mg} \mathrm{day}^{-1}$. Results showed that apples could significantly contribute to the total consumption of phenolics in diet, especially for people with special diet requirements.

Total phenols and total flavonoids content in fresh apples and apple purees

\begin{tabular}{|c|c|c|c|c|}
\hline Cultivars & $\begin{array}{c}\text { TPC, } \\
\text { mg GAE } 100 \mathrm{~g}^{-1}\end{array}$ & $\begin{array}{c}\text { TFC, } \\
\text { mg CE } 100 \mathrm{~g}^{-1} \\
\end{array}$ & $\begin{array}{c}\text { DPPH; } \\
\text { mmol TE } 100 \mathrm{~g}^{-1} \\
\end{array}$ & $\begin{array}{c}\text { ABTS }^{+}, \\
\text {mmol TE } 100 \mathrm{~g}^{-1} \\
\end{array}$ \\
\hline \multicolumn{5}{|l|}{ Fresh apples } \\
\hline 'Antonovka' & $115.25 \pm 4.61^{\mathrm{d}^{*}}$ & $78.41 \pm 2.58^{\mathrm{b}}$ & $9.22 \pm 0.58^{c}$ & $6.21 \pm 0.33^{\mathrm{cd}}$ \\
\hline 'Filippa' & $89.65 \pm 4.14^{\mathrm{c}}$ & $82.06 \pm 2.75^{\mathrm{c}}$ & $3.26 \pm 0.18^{\mathrm{ab}}$ & $6.72 \pm 0.41^{\mathrm{d}}$ \\
\hline 'Nicnera Zemenu' & $85.84 \pm 1.11^{\mathrm{c}}$ & $83.93 \pm 3.31^{\mathrm{c}}$ & $3.55 \pm 0.14^{b}$ & $5.80 \pm 0.28^{c}$ \\
\hline 'Rudens Svitrotais' & $68.21 \pm 2.05^{\mathrm{a}}$ & $36.70 \pm 2.71^{\mathrm{a}}$ & $3.09 \pm 0.18^{\mathrm{a}}$ & $3.36 \pm 0.11^{\mathrm{a}}$ \\
\hline 'Sipolins' & $79.10 \pm 2.98^{\mathrm{b}}$ & $76.01 \pm 2.83^{b}$ & $2.88 \pm 0.11^{\mathrm{a}}$ & $4.01 \pm 0.18^{\mathrm{b}}$ \\
\hline \multicolumn{5}{|l|}{ Apple purees } \\
\hline 'Antonovka' & $193.22 \pm 4.25^{\mathrm{e}}$ & $140.59 \pm 3.53^{\mathrm{d}}$ & $9.81 \pm 0.60^{c}$ & $16.83 \pm 0.23^{\mathrm{c}}$ \\
\hline 'Filippa' & $152.25 \pm 2.07^{b}$ & $102.74 \pm 3.21^{\mathrm{c}}$ & $8.09 \pm 0.28^{\mathrm{a}}$ & $13.73 \pm 0.15^{\mathrm{b}}$ \\
\hline 'Nicnera Zemenu' & $179.55 \pm 5.11^{\mathrm{d}}$ & $99.74 \pm 1.19^{c}$ & $9.58 \pm 0.07^{c}$ & $16.85 \pm 0.20^{\mathrm{c}}$ \\
\hline 'Rudens Svitrotais' & $165.31 \pm 5.93^{c}$ & $48.91 \pm 3.08^{\mathrm{a}}$ & $8.96 \pm 0.09^{b}$ & $14.14 \pm 0.42^{\mathrm{b}}$ \\
\hline 'Sipolins' & $133.85 \pm 1.20^{\mathrm{a}}$ & $91.69 \pm 2.12^{\mathrm{b}}$ & $7.96 \pm 0.29^{\mathrm{a}}$ & $12.82 \pm 0.32^{\mathrm{a}}$ \\
\hline
\end{tabular}

* Different small letters in the same column represents significant differences between values (Tukey's test, $\mathrm{p}<0.05$ ) for fresh apples and apple purees separately.

Flavonoids is an important class of phenolic compounds showing different health benefits. The highest content was detected in 'Filippa' and 'Nicnera Zemenu' apples, whereas in purees the highest content again was detected in 'Antonovka', showing higher stability of compounds presented in these apples. In apples flavonoids proportion decreased, except 'Antonovka'. 'Rudens Svitrotais' had the lowest proportion of flavonoids in their phenolic content that could explain also following lower antioxidant activity. Radical scavenging activity was the highest for cultivar 'Antonovka' apples and in apple puree the highest activity was in two cultivars 'Antonovka', 'Nicnera Zemenu' purees.

Table 4

Correlation matrix between TPC, TFC and radical scavenging activity

\begin{tabular}{lcccc}
\hline & TPC & TF & DPPH & ABTS \\
\hline TPC & 1.00 & & & \\
TF & 0.61 & 1.00 & & \\
DPPH & 0.91 & 0.48 & 1.00 & \\
ABTS & 0.97 & 0.60 & 0.83 & 1.00 \\
\hline
\end{tabular}

Several authors reported positive correlation between phenolic content and antioxidant activity in apples (Fernández-Jalao et al., 2018; Ferrentino et al., 2018) and in the current study similar results were obtained (Table 4). Total phenolic content had a strong positive correlation with radical scavenging activity by both tests - DPPH and ABTS. Whereas there was a moderate correlation between total flavonoids and antioxidant activity. Generally, phenolic compounds are important factors influencing antioxidant activity of different fruits (Park et al., 2015)

\section{Conclusions}

Apples are a good source of some bioactive compounds as phenolic compounds and influence of cultivar on the quality parameters is significant. 'Antonovka' is rich in ascorbic acid, phenolic compounds and shows antioxidant activity, but other parameters as soluble solids are lower. The $\mathrm{pH}$ of cultivar 'Antonovka' was even lower than 3.0 and, therefore, this cultivar is not recommended for puree of special diets. The cultivar 'Nicnera Zemenu' has the highest ascorbic acid content in processed puree, the highest soluble solids content and also the lowest $\mathrm{pH}$ and titratable acids content. Therefore, data obtained in this study are essential for selecting of raw materials for development of new products for special diets.

\section{Acknowledgment}

This study was supported by European Innovation Partnership for Agricultural Productivity and Sustainability Working Group Cooperation Project No. 18-00-A01612-000006. 


\section{References}

1. Archivio M. D., Filesi C., Benedetto R. Di, Gargiulo R., Giovannini C., Masella R. (2007) Polyphenols, dietary sources and bioavailability. Annali dell'Istituto Superiore di Sanità, Vol. 43(4), p. 348-361.

2. Bonany J., Brugger C., Buehler A., Carbó J., Codarin S., Donati F., Echeverria G., Egger S., Guerra W., Hilaire C., Höller I., Iglesias I., Jesionkowska K., Konopacka D., Kruczynska D., Martinelli A., Petiot C., Sansavini S., Stehr R., Schoorl F. (2014) Preference mapping of apple varieties in Europe. Food Quality and Preference, Vol. 32(PC), p. 317-329.

3. Boyer J., Liu R. (2004) Apple phytochemicals and their health benefits: Review. Nutrition Journal, Vol. 3(5), p. 1-15.

4. Cichero J.A.Y., Lam P., Steele C.M., Hanson B., Chen J., Dantas R. O., Duivestein J., Kayashita J., Lecko C., Murray J., Pillay M., Riquelme L., Stanschus S. (2017) Development of international terminology and definitions for texture-modified foods and thickened fluids used in dysphagia management: The IDDSI framework. Dysphagia, Vol. 32(2), p. 293-314.

5. Delgado-Pelayo R., Gallardo-Guerrero L., HorneroMéndez D. (2014) Chlorophyll and carotenoid pigments in the peel and flesh of commercial apple fruit varieties. Food Research International, Vol. 65(PB), p. 272-281.

6. Drogoudi P. D., Michailidis Z., Pantelidis G. (2008) Peel and flesh antioxidant content and harvest quality characteristics of seven apple cultivars. Scientia Horticulturae, Vol. 115(2), p. 149-153.

7. Ercilla M., Ripa C., Gayan M., Arteche J.M., Odriozola B., Bello M.C., Barral I. (2012) Prevalence of dysphagia in the older using 'Eating Assessment Tool-10.' European Journal of Hospital Pharmacy: Science and Practice, Vol. 19(2), p. 205-206.

8. Espinosa L., To N., Symoneaux R., Renard C.M.G.C., Biau N., Cuvelier G. (2011) Effect of processing on rheological, structural and sensory properties of apple puree. Procedia Food Science, Vol. 1, p. 513-520.

9. Fernández-Jalao I., Sánchez-Moreno C., De Ancos B. (2018) Effect of high-pressure processing on flavonoids, hydroxycinnamic acids, dihydrochalcones and antioxidant activity of apple 'Golden Delicious' from different geographical origin. Innovative Food Science and Emerging Technologies, Vol. 51, p. 20-31.

10. Ferrentino G., Morozova K., Mosibo O. K., Ramezani M., Scampicchio M. (2018) Biorecovery of antioxidants from apple pomace by supercritical fluid extraction. Journal of Cleaner Production, Vol. 186, p. 253-261.

11. Floegel A., Kim D.O., Chung S. J., Koo S.I., Chun O.K. (2011) Comparison of ABTS/DPPH assays to measure antioxidant capacity in popular antioxidant-rich US foods. Journal of Food Composition and Analysis, Vol. 24(7), p. 1043-1048.

12. Francini A., Sebastiani L. (2013) Phenolic Compounds in Apple (Malus x domestica Borkh.): Compounds characterization and stability during postharvest and after processing. Antioxidants, Vol. 2(3), p. 181-193.

13. Gogia N., Gongadze M., Bukia Z., Esaiashvili M.V., Chkhikvishvili I. (2014) Total polyphenols and antioxidant activity in different species of apples grown in Georgia. Georgian Medical News, Vol. 232-233, p. 107-112.

14. Hartmann A., Patz C.D., Andlauer W., Dietrich H., Ludwig M. (2008) Influence of processing on quality parameters of strawberries. Journal of Agricultural and Food Chemistry, Vol. 56(20), p. 9484-9489.
15. Ilhamto N., Anciado K., Keller H.H., Duizer L.M. (2014) In-house pureed food production in long-term care: perspectives of dietary staff and implications for improvement. Journal of Nutrition in Gerontology and Geriatrics, Vol. 33(3), p. 210-228.

16. Jakobek L., Barron A.R. (2016) Ancient apple varieties from Croatia as a source of bioactive polyphenolic compounds. Journal of Food Composition and Analysis, Vol. 45, p. 9-15.

17. Kalinowska M., Bielawska A., Lewandowska-Siwkiewicz H., Priebe W., Lewandowski W. (2014) Apples: Content of phenolic compounds vs. variety, part of apple and cultivation model, extraction of phenolic compounds, biological properties. Plant Physiology and Biochemistry, Vol. 84, p. 169-188.

18. Kampuse S., Ozola L., Straumite E., Galoburda R. (2015) Quality parameters of wheat bread enriched with pumpkin (Cucurbita Moschata) by-products. Acta Universitatis Cibiniensis. Series E: Food Technology, Vol. 19(2), p. 3-14.

19. Karaman Ş., Tütem E., Başkan K.S., Apak R. (2013) Comparison of antioxidant capacity and phenolic composition of peel and flesh of some apple varieties. Journal of the Science of Food and Agriculture, Vol. 93(4), p. 867-875.

20. Keenan D.F., Valverde J., Gormley R., Butler F., Brunton N.P. (2012) Selecting apple cultivars for use in ready-to-eat desserts based on multivariate analyses of physico-chemical properties. LWT-Food Science and Technology, Vol. 48(2), p. 308-315.

21. Keller H., Chambers L., Niezgoda H., Duizer L. (2012) Issues associated with the use of modified texture foods. The Journal of Nutrition, Health \& Aging, Vol. 16(3), p. 195-200.

22. Keller H.H., Duizer L.M. (2014) What do consumers think of pureed food? Making the most of the indistinguishable food. Journal of Nutrition in Gerontology and Geriatrics, Vol. 33(3), p. 139-159.

23. Kim D.O., Jeong S.W., Lee C.Y. (2003) Antioxidant capacity of phenolic phytochemicals from various cultivars of plums. Food Chemistry, Vol. 81(3), p. 321-326.

24. Laaksonen O., Kuldjärv R., Paalme T., Virkki M., Yang B. (2017) Impact of apple cultivar, ripening stage, fermentation type and yeast strain on phenolic composition of apple ciders. Food Chemistry, Vol. 233, p. 29-37.

25. MK noteikumi nr. 1113 Prasības attiecībā uz augḷu sulām un tām līdzīgiem produktiem [The regulation of the Cabinet of Ministers of Latvia no. 1113, October 15, 2013 regarding fruit juices and similar products] (in Latvian).

26. Park Y.S., Im M.H., Ham K.S., Kang S.G., Park Y.K., Namiesnik J., Leontowicz H., Leontowicz M., Trakhtenberg S., Gorinstein, S. (2015) Quantitative assessment of the main antioxidant compounds, antioxidant activities and FTIR spectra from commonly consumed fruits, compared to standard kiwi fruit. LWT-Food Science and Technology, Vol. 63(1), p. 346-352.

27. Pfisterer K.J., Amelard R., Chung A.G., Wong A. (2018) A new take on measuring relative nutritional density: The feasibility of using a deep neural network to assess commercially-prepared puréed food concentrations. Journal of Food Engineering, Vol. 223, p. 220-235.

28. Riekstina-Dolge R., Kruma Z., Dimins F., Straumite E., Karklina D. (2014) Phenolic composition and sensory properties of ciders produced from Latvian apples. 
Proceedings of Latvia University of Agriculture, Vol. 31(326), p. 41-45.

29. Segliṇa D. (2007). Smiltsērkšḳu aug̣̦i un to pārstrādes produkti [Sea buckthorn fruits and their processing products]. Summary of promotion work for acquiring the Doctor's degree in Engineering Sciences in the Food Science. (in Latvian)

30. Singleton V.L., Orthofer R., Lamuela-Raventos R.M. (1999) Analysis of total phenols and other oxidation substrates and antioxidants by means of FolinCiocalteu reagent. Methods in Enzymology, Vol. 119(25), p. $152-178$.

31. Song Y., Yao Y. X., Zhai H., Du Y. P., Chen F., Wei S. W. (2007) Polyphenolic compound and the degree of browning in processing apple varieties. Agricultural Sciences in China, Vol. 6(5), p. 607-612.

32. Varming C., Petersen M.A., Toldam-Andersen T.B. (2013) Ascorbic acid contents in Danish apple cultivars and commercial apple juices. LWT-Food Science and Technology, Vol. 54(2), p. 597-599.

33. Weichselbaum E., Wyness L., Stanner S. (2010) Apple polyphenols and cardiovascular disease - A review of the evidence. Nutrition Bulletin, Vol. 35(2), p. 92-101.

34. Yu L., Perret J., Harris M., Wilson J., Haley S. (2003) Antioxidant properties of bran extracts from "Akron" wheat grown at different locations. Journal of Agricultural and Food Chemistry, Vol. 51(6), p. 1566-1570. 